\title{
Inventory of free-ranging lions Panthera leo in Africa
}

\author{
H. Bauer and S. Van Der Merwe
}

\begin{abstract}
The number of free ranging African lions Panthera leo has never been comprehensively assessed. We present an inventory of available information, covering most protected areas and ranging in quality from educated guesses to individually known populations. This gives a conservative estimate of 16,500-30,000 free ranging lions in Africa. The inventory shows that popu-
\end{abstract}

lations are small and fragmented in West and Central Africa, whereas the species still occurs widely in East and Southern Africa. The results concur with the current IUCN Red List categorization of the lion as Vulnerable.

Keywords Africa, inventory, lion, Panthera leo, Red List.

\section{Introduction}

Lions Panthera leo once roamed large parts of Africa, Europe, the Middle East and Asia. They disappeared from Europe during the first century $\mathrm{AD}$ and from North Africa, the Middle East and Asia between 1800 and 1950, except for one population of the subspecies $P$. leo persica in India. Lions are today found in savannah habitats across sub-Saharan Africa (Nowell \& Jackson, 1996).

The African lion is classified as Vulnerable on the IUCN Red List, with agriculture, human settlement and poisoning indicated as the main threats (IUCN, 2002). This classification was partly based on an educated guess of between 30,000 and 100,000 free ranging lions (Nowell \& Jackson, 1996). The large margin was justified by lack of information and the difficulty of conducting lion censuses (Loveridge et al., 2001; Mills et al., 2001). The African Lion Working Group, affiliated with IUCN, took the initiative to gather the available information for a more precise estimate, and this paper presents the results of this exercise.

\section{Methods}

Requests for information were sent to researchers, wildlife departments and conservationists, and an information sharing workshop for West and Central Africa was organized in Cameroon in 2001 (Bauer et al., 2001). Information gaps were filled by specific requests to

H. Bauer (Corresponding author) Institute of Environmental Sciences, Leiden University, P.O. Box 9518, 2300 RA Leiden, The Netherlands. E-mail bauer@cml.leidenuniv.nl

S. Van Der Merwe African Lion Working Group, P.O. Box 12451, Brandhof 9324, Bloemfontein, South Africa. E-mail mwnatura@mweb.co.za

Received 21 November 2002. Revision requested 16 June 2003. Accepted 5 September 2003. individuals or conservation networks. In total nearly 100 people provided information. Information was also obtained from relevant literature, but data $>10$ years old were not included. The inventory is thus based on existing information, except for Zambia, which was surveyed especially for this inventory.

Individuals contacted were requested to indicate their method of estimation and an estimate of lion numbers (in 2001 or 2002 unless indicated otherwise) with an indication of minimum and maximum values. In a few cases these values were $95 \%$ confidence limits, but most sources could only indicate the lowest and highest conceivable estimate. For a few areas we had estimates from two or three equally authoritative sources; we included the mean estimate with the extreme values and indicated both sources. If minimum and maximum values were not provided, they were generated depending on the method of estimation, using a percentage of the estimate, viz:

1. Estimate $\pm 10 \%$, based on a total count, with all lions in an area individually identified by features such as whisker spots, scars and nose colour (Pennycuick \& Rudnai, 1970). This is the most accurate census method.

2. Estimate $\pm 20 \%$, based on total or sample area inventory with the aid of calling stations, with or without bait, using hyaena and/or prey sounds to attract lions. Calling station methods and precision vary between areas and researchers; confidence limits were reported to be 3\% in the Masai Mara National Reserve (Ogutu \& Dublin, 1998), but these limits are expected to be higher under most conditions, and up to $90 \%$ depending on habitat (Mills et al., 2001).

3 . Estimate $\pm 30 \%$, based on mark-recapture experiments, use of radio collars and tourist picture databases (Smuts et al., 1977; Creel \& Creel, 1997; Loveridge et al., 2001); most studies in this category combine several of these methods. Spoor counts are included in this category, but the methodology has to be further developed to improve accuracy and precision (Stander, 1998). 
4. Estimate $\pm 40 \%$, with estimate based on fieldwork and an informed guess by a resident researcher with intimate knowledge of an area, preferably based on prey censuses.

5. Estimate $\pm 50 \%$, with a 'best guess' based on short visits and secondary data, such as prey or hyaena numbers, size of area, rainfall and other factors (East, 1984; Van Orsdol et al., 1985).

6. Minimum and maximum values specified by the source, with other methods of estimation or information obtained under special circumstances.

Counts based on aerial, dung and roaring surveys were considered inappropriate methods and were not included. We present subtotals and totals under 5,000 rounded to the nearest 50 and over 5,000 to the nearest 500 .

\section{Results}

The results for each protected area, ecosystem or region are presented in Table 1 and the geographical distribution of lions is illustrated in Fig. 1. The estimate for West and Central Africa together was 1,800, with all populations being small and fragmented over the region. As few systematic surveys have been carried out in this part of the continent the information is mostly based on best guesses. The estimate for East Africa was 11,000, with the continent's two largest populations in the Serengeti and Selous ecosystems of Tanzania. The estimate for

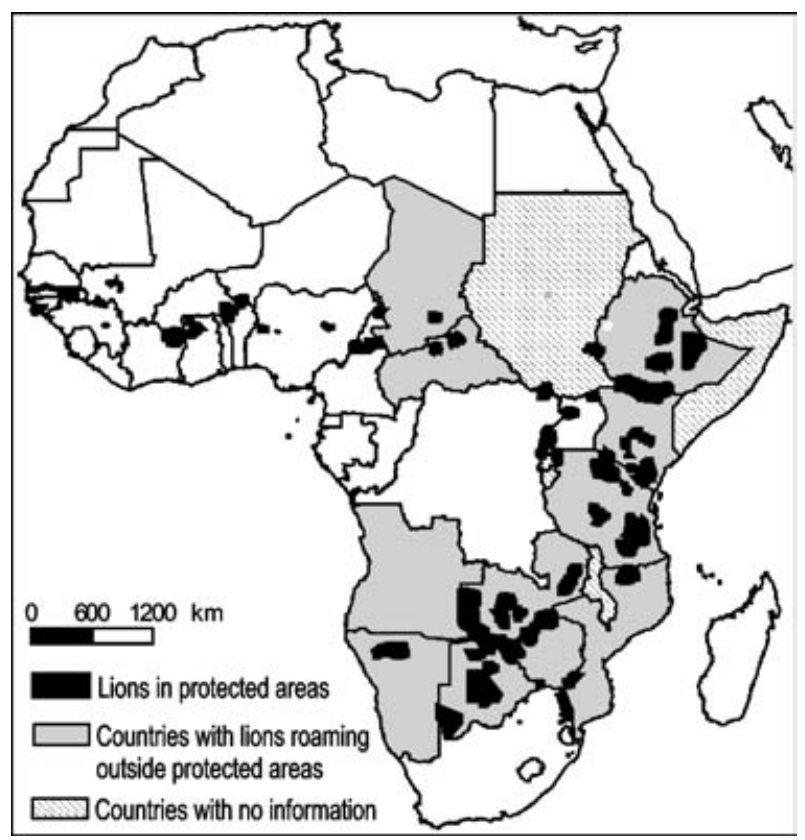

Fig. 1 Map of Africa illustrating the location of lion populations. Protected areas with lions, as listed in Table 1, are in black, and countries with substantial numbers of lions outside protected areas are in grey. Information in Table 1 that has no specific geographic denomination is not illustrated
Southern Africa was 10,000, with the majority in Botswana and South Africa. Methods 1 to 3, with minimum and maximum values of $10-30 \%$ of the estimate, accounted for c. $30 \%$ of the total continental estimate of 23,000 lions, and $70 \%$ was established with methods 4 to 6 , with minimum and maximum values of $40-50 \%$ or as specified by the source. The estimated minimum and maximum values of the total lion population were 16,500 and 30,000 , respectively.

\section{Discussion}

Some figures in Table 1 are marked as disputed. In the case of Kruger National Park, the source stated that minimum and maximum values were inappropriate for the research conditions (G. Mills, pers. comm.). S. Creel (pers. comm.) provided an estimate for the Selous population, despite the paucity of data; C. Packer and J. Scott (pers. comm.) questioned the figure but did not propose an alternative and agreed that the estimate reflected the true order of magnitude. For the Central Kalahari area, P. Funston (pers. comm.) estimated the lion population at 517, higher than the estimate of the Botswana Department of Wildlife and National Parks. J. Anderson (pers. comm.) stated that the last two lions in Odzilla National Park, Congo, were shot in 1994, but C. Aveling (pers. comm.) reported that there could still be up to 25 individuals. Nowell \& Jackson (1996) stated that lions were extinct in Gabon whereas some sources suggested that there may be lions on the Bateke Plateau. A recent survey in that area found that the last lion was shot in 1999. A few small savannah patches near Mpassa were not surveyed; these could theoretically contain 0-10 lions (P. Henschl, pers. comm.). For Niokolo Koba National Park, Senegal, the warden indicated that the only figure ever published, 120 in 1977, should be listed (Dupuy \& Verschuren, 1977; I. Diop, pers. comm.). Another source, however, estimated the population at 20, based on extensive travel and interviews in 2001 (O. Burnham, pers. comm.). A third source used several methods and estimated 50-150 lions in 1996 (I. Di Silvestre, pers. comm.).

The results, based on extensive enquiries and estimates of differing degrees of precision, were obtained for all but a few areas, listed in Table 1 as "not available" or "present, not estimated". Of these areas, we expect the Ruaha and Tarangire ecosystems in Tanzania to contain substantial numbers of lions. The other areas have been described as depleted of natural resources (East, 1999) and therefore we expect their lion populations to have a marginal impact on the total estimate. Many rural nonprotected areas in East and Southern Africa contain lions (G. Mills, pers. comm.), in contrast to West and Central Africa (Bauer et al., 2003). Some of these areas were included but others have never been surveyed, although 
Table 1 Estimates of lion populations in Africa, for 2001/2002 unless indicated otherwise, with minimum and maximum estimates, the method used for estimation (see text for details), and the data source (individuals or reference). Lions in conservation areas adjacent to National Parks were included in the figures for the Parks. Some contiguous protected areas were designated by the name of the most prominent area followed by 'ecosystem'.

\begin{tabular}{|c|c|c|c|c|c|}
\hline Country or region & $\begin{array}{l}\text { Ecosystem, location or National Park } \\
(\mathrm{NP})\left(\text { area in } \mathrm{km}^{2}\right)^{1}\end{array}$ & Estimate & Min. & Max. & $\begin{array}{l}\text { Estimation method } \\
\text { (pers. comm. or reference) }\end{array}$ \\
\hline North Africa & All ecosystems & 0 & 0 & 0 & 6 (Nowell \& Jackson, 1996) \\
\hline Benin & Pendjari ecosystem $(6,505)$ & 45 & 39 & 52 & 2 (I. Di Silvestre, A. Tehou) \\
\hline Benin & Remainder & 20 & 12 & 28 & 4 (A. Tehou) \\
\hline Burkina Faso & Arly-Singou ecosystem $(6,388)$ & 100 & 50 & 150 & 5 (P. Bouche, H. Bauer) \\
\hline Côte d' Ivoire & Comoe NP $(11,500)$ & 30 & 15 & 45 & 5 (F. Fischer, H. Bauer) \\
\hline Gambia & National & 0 & 0 & 0 & 5 (H. Bauer) \\
\hline Ghana & Gbele Reserve $(1,226)$ & 10 & 6 & 14 & 4 (Ghana Wildlife Society) \\
\hline Ghana & Mole NP $(4,921)$ & 20 & 12 & 28 & 4 (Ghana Wildlife Society) \\
\hline Guinea & Guinea-Mali Protected Area & 120 & 60 & 180 & 5 (A. Oulare) \\
\hline Guinea & Remainder & 80 & 40 & 120 & 5 (A. Oulare) \\
\hline Guinea-Bissau & Doulombi / Boe NP $(1,500)$ & 30 & 15 & 45 & 5 (D. Fai) \\
\hline Liberia & National & 0 & 0 & 0 & 5 (Garnett \& Utas, 2000) \\
\hline Mali & National & 50 & 25 & 75 & 5 (Moriba) \\
\hline Mauritania & National & 0 & 0 & 0 & 6 (Nowell \& Jackson, 1996) \\
\hline Niger & "W" NP $(2,977)$ & 70 & 49 & 91 & 3 (Moussa \& P. Gay) \\
\hline Nigeria & National & 200 & 100 & 300 & 5 (P. Jenkins) \\
\hline Senegal & Niokolo Koba ecosystem² $(19,130)$ & 60 & 20 & 150 & $\begin{array}{l}6 \text { (O. Burnham, I. Diop \& } \\
\text { I. Di Silvestre) }\end{array}$ \\
\hline Sierra Leone & National & 0 & 0 & 0 & 5 (Garnett \& Utas, 2000) \\
\hline Togo & National & 0 & 0 & 0 & 6 (Nowell \& Jackson, 1996) \\
\hline Subtotal & West Africa & 850 & 450 & 1,300 & \\
\hline Cameroon & Benoue ecosystem $(30,000)$ & 200 & 100 & 400 & 6 (P. Aarhaug \& H. Bauer) \\
\hline Cameroon & Waza NP $(1,700)$ & 60 & 42 & 78 & 3 (H. Bauer) \\
\hline Central African Republic & National & 300 & 150 & 500 & 5 (P. Scholte) \\
\hline Chad & Zakouma ecosystem $(3,000)$ & 50 & 25 & 75 & 5 (P. Scholte) \\
\hline Chad & Remainder & 100 & 50 & 150 & 5 (P. Scholte) \\
\hline Congo & Odzilla NP² $(2,848)$ & 0 & 0 & 25 & 6 (J. Anderson \& C. Aveling) \\
\hline Democratic Rep. of Congo & Virunga NP $(7,800)$ & 90 & 60 & 125 & 5 (M. Languy) \\
\hline Democratic Rep. of Congo & Garamba NP $(12,477)$ & 150 & 100 & 200 & 5 (F. Smith \& M. Languy) \\
\hline Equatorial Guinea & National & 0 & 0 & 0 & 6 (Nowell \& Jackson, 1996) \\
\hline Gabon & National $^{2}$ & 0 & 0 & 0 & 6 (Nowell \& Jackson, 1996) \\
\hline Subtotal & Central Africa & 950 & 550 & 1,550 & \\
\hline Burundi & National & \multicolumn{4}{|c|}{ Not available } \\
\hline Djibouti & National & 0 & 0 & 0 & 6 (Nowell \& Jackson, 1996) \\
\hline Ethiopia & Babile, Darkata. Webe Shebelle & 300 & 180 & 420 & 4 (S. Williams \& C. Sillero-Zubiri) \\
\hline Ethiopia & Bale, Sof Omar & 50 & 30 & 70 & 4 (S. Williams \& C. Sillero-Zubiri) \\
\hline Ethiopia & Borana, L. Stephanie, L. Turkana & 100 & 60 & 140 & 4 (S. Williams \& C. Sillero-Zubiri) \\
\hline Ethiopia & Gambella & 150 & 90 & 210 & 4 (S. Williams \& C. Sillero-Zubiri) \\
\hline Ethiopia & North East & 250 & 200 & 300 & 6 (S. Williams \& C. Sillero-Zubiri) \\
\hline Ethiopia & Omo NP, Mago NP & \multicolumn{3}{|c|}{ Present, not estimated } & 6 (S. Williams \& C. Sillero-Zubiri) \\
\hline Ethiopia & Remainder & 150 & 75 & 225 & 5 (S. Williams \& C. Sillero-Zubiri) \\
\hline Kenya & Aberdares NP $(1,966)$ & 7 & 5 & 15 & 6, 2000 (B. Heath) \\
\hline Kenya & Amboseli NP (392) & 20 & 20 & 20 & 4 (C. Packer) \\
\hline Kenya & $\begin{array}{l}\text { East of Rift Valley to the East of the } \\
\text { Matthews, Ndotos, Mt Nyiru }\end{array}$ & \multicolumn{3}{|c|}{ Present, not estimated } & 6 (S. Williams) \\
\hline Kenya & Galana Game Ranch & 150 & 75 & 150 & 5 (B. Heath) \\
\hline Kenya & Isiolo, Barsalinga, Wamba, Shaba & 100 & 75 & 125 & 4 (S. Williams) \\
\hline Kenya & Kora National Reserve & 40 & 20 & 60 & 5 (M. Jenkins) \\
\hline Kenya & Laikipia Plateau $(10,000)$ & 120 & 96 & 144 & 2 (L. Frank) \\
\hline Kenya & Masai Mara NP $(1,670)$ & 547 & 492 & 602 & 1 (Ogutu \& Dublin, 2002) \\
\hline Kenya & Meru NP, Bisanadi Reserve $(5,273)$ & 80 & 40 & 120 & 5 (L. Frank) \\
\hline Kenya & Nairobi NP (117) & 22 & 22 & 22 & 2 (J. Cavanaugh \& C. Packer) \\
\hline Kenya & Nakuru NP (98) & 28 & 17 & 39 & 4 (L. Hannah \& J. Dawson) \\
\hline Kenya & North of Tana, East of Rift Valley & 650 & 325 & 1,300 & 5 (S. Williams) \\
\hline
\end{tabular}


Table 1 (Continued)

\begin{tabular}{|c|c|c|c|c|c|}
\hline Country or region & $\begin{array}{l}\text { Ecosystem, location or National Park } \\
(\mathrm{NP})\left(\text { area in } \mathrm{km}^{2}\right)^{1}\end{array}$ & Estimate & Min. & Max. & $\begin{array}{l}\text { Estimation method } \\
\text { (pers. comm. or reference) }\end{array}$ \\
\hline Kenya & Tsavo NP $(40,000)$ & 675 & 338 & 1,350 & 5 (C. Packer \& B. Heath) \\
\hline Kenya & Remainder & \multicolumn{3}{|c|}{ Present, not estimated } & 6 (S. Williams) \\
\hline Rwanda & Akagera NP $(1,500)$ & 25 & 15 & 35 & 4 (S. Williams) \\
\hline Somalia & National & \multicolumn{4}{|c|}{ Not available } \\
\hline Sudan & National & \multicolumn{3}{|c|}{ Present, not estimated } & 6 (G. Steehouwer) \\
\hline Tanzania & Manyara NP (325) & 20 & 20 & 20 & 4 (C. Packer) \\
\hline Tanzania & Ngorongoro Crater $(4,081)$ & 53 & 53 & 53 & 1 (C. Packer) \\
\hline Tanzania & Selous Game Reserve $(92,000)$ & 3,750 & 3,000 & 4,500 & 5 (S. Creel) \\
\hline Tanzania & Buffer zone around Selous & 750 & 500 & 1,000 & 6 (S. Creel) \\
\hline Tanzania & Serengeti ecosystem $(40,000)$ & 2,500 & 1,750 & 3,250 & 3 (C. Packer) \\
\hline Tanzania & Tarangire and Ruaha ecosystem & \multicolumn{3}{|c|}{ Present, not estimated } & 6 (C. Packer) \\
\hline Uganda & Kidepo Valley NP $(1,340)$ & 25 & 20 & 30 & 2 (L. Siefert \& M. Dricuru) \\
\hline Uganda & Murchison Falls ecosystem $(5,198)$ & 350 & 280 & 420 & 2 (L. Siefert \& M. Dricuru) \\
\hline Uganda & Queen Elizabeth ecosystem $(3,233)$ & 200 & 140 & 260 & 2 (L. Siefert \& M. Dricuru) \\
\hline Subtotal & East Africa & 11,000 & 8,000 & 15,000 & \\
\hline Angola & National & 450 & 270 & 630 & 4 (W. Van Hoven) \\
\hline Botswana & Central Kalahari Game Reserve ${ }^{2}(52,000)$ & 312 & 166 & 458 & $\begin{array}{l}6 \text { (P. Funston \& Department of Wildlife } \\
\text { and National Parks) }\end{array}$ \\
\hline Botswana & Kgalagadi Transfrontier Park $(38,000)$ & 458 & 428 & 478 & 6 (P. Funston) \\
\hline Botswana & $\begin{array}{l}\text { Southern Kgalagadi Wildlife Management } \\
\text { Areas }^{2}\end{array}$ & 225 & 200 & 250 & 6 (P. Funston) \\
\hline Botswana & Dry North & 223 & 133 & 312 & 4, 2000 (C. Winterbach \& L. Sechele) \\
\hline Botswana & Kwando, Chobe River & 213 & 149 & 277 & 3 (C. Winterbach \& L. Sechele) \\
\hline Botswana & Okavango Delta $(80,000)$ & 1,438 & 1,006 & 1,869 & $\begin{array}{l}3 \text { (P. Kat, C. Winterbach, H. Winterbach } \\
\quad \& \text { L. Sechele) }\end{array}$ \\
\hline Botswana & Makgadigadi Pans NP $(2,836)$ & 39 & 28 & 59 & 2 (G. Hemson) \\
\hline Botswana & Nxai Pan $(1,817)$ & \multicolumn{3}{|c|}{ Present, not estimated } & 6 (G. Hemson) \\
\hline Botswana & Tuli Block & 10 & 0 & 20 & 6 (C. Winterbach \& H. Winterbach) \\
\hline Lesotho & National & 0 & 0 & 0 & 6 (J. Naude) \\
\hline Malawi & National & \multicolumn{4}{|c|}{ Not available } \\
\hline Mozambique & Manica Gaza & 25 & 15 & 35 & 4 (J. Anderson) \\
\hline Mozambique & Niassa, Cabo Delgado $(15,000)$ & 175 & 105 & 245 & 4 (J. Anderson) \\
\hline Mozambique & Zambezi Valley & 175 & 105 & 245 & 4 (J. Anderson) \\
\hline Mozambique & Remainder & 25 & 15 & 35 & 4 (J. Anderson) \\
\hline Namibia & Etosha NP $(22,270)$ & 230 & 191 & 266 & 6 (P. Stander) \\
\hline Namibia & Remainder & 680 & 476 & 884 & 3 (P. Stander) \\
\hline South Africa & $\begin{array}{l}\text { Eastern Cape: Addo Elephant Park, } \\
\text { Kwande, Shamwari }\end{array}$ & 13 & 12 & 14 & 1 (R. Slotow \& G. Van Dyk) \\
\hline South Africa & Kruger ecosystem $^{2}(23,700)$ & 2,200 & 2,200 & 2,200 & 6 (G. Mills) \\
\hline South Africa & Hluluwe-Umfolozi NP (965) & 120 & 72 & 168 & 4 (R. Slotow) \\
\hline South Africa & Phinda, St Lucia, Thembe, Ndumu & 15 & 15 & 15 & 1 (R. Slotow \& G. Van Dyk) \\
\hline South Africa & Lowveld region & 161 & 153 & 169 & $\begin{array}{l}6 \text { (S. Liversage, I. Sussens, T. Yule, } \\
\text { L. van Losenoord, C. Jones, } \\
\text { G. Thomson, R. Niemann, } \\
\text { P. Owen, M. Pieterse) }\end{array}$ \\
\hline South Africa & Venetia Limpopo Mine (400) & 30 & 15 & 45 & 5 (J. Kruger) \\
\hline South Africa & Ligwalagwala - near Malelane & 13 & 13 & 13 & 1 (R. Slotow) \\
\hline South Africa & Madikwe, Pilanesberg (550) & 110 & 99 & 121 & 1 (G. Van Dyk) \\
\hline South Africa & Kgalagadi Transfrontier Park & \multicolumn{4}{|c|}{ See Botswana } \\
\hline South Africa & Tswalu & \multicolumn{4}{|c|}{ Not available } \\
\hline South Africa & Waterberg Region & 54 & 54 & 54 & 1 (R. Slotow \& G. Van Dyk) \\
\hline Swaziland & Hlane Royal NP (163) & 15 & 15 & 15 & 1 (J. Naude) \\
\hline Zambia & $\begin{array}{l}\text { Kafue NP, Luangua Valley and Lower } \\
\text { Zambezi NP }\end{array}$ & 1,500 & 1,000 & 2,000 & 6 (C. Stuart \& T. Stuart) \\
\hline Zimbabwe & Charara Safari Area $(2,207)$ & 40 & 24 & 56 & 4 (N. Monks) \\
\hline Zimbabwe & Chete, Sijarira Safari Area & 40 & 24 & 56 & 4 (N. Monks) \\
\hline Zimbabwe & Chewore Safari Area $(2,704)$ & 100 & 60 & 140 & 4 (N. Monks) \\
\hline Zimbabwe & Chirisa Safari Area $(1,788)$ & 40 & 24 & 56 & 4 (N. Monks) \\
\hline
\end{tabular}


Table 1 (Continued)

\begin{tabular}{|c|c|c|c|c|c|}
\hline Country or region & $\begin{array}{l}\text { Ecosystem, location or National Park } \\
(\mathrm{NP})\left(\text { area in } \mathrm{km}^{2}\right)^{1}\end{array}$ & Estimate & Min. & Max. & $\begin{array}{l}\text { Estimation method } \\
\text { (pers. comm. or reference) }\end{array}$ \\
\hline Zimbabwe & Chizarira NP $(1,878)$ & 60 & 36 & 84 & 4 (N. Monks) \\
\hline Zimbabwe & Dande Safari Area (988) & 50 & 30 & 70 & 4 (N. Monks) \\
\hline Zimbabwe & Doma Safari Area $(1,933)$ & 35 & 21 & 49 & 4 (N. Monks) \\
\hline Zimbabwe & $\begin{array}{l}\text { Gonarezhou, Save, Chiredzi, Malilangwe, } \\
\text { Beit Bridge, Tuli }(5,200)\end{array}$ & 130 & 91 & 169 & 3 (C. Wenham) \\
\hline Zimbabwe & Hurungwe Safari Area $(2,606)$ & 80 & 48 & 112 & 4 (N. Monks) \\
\hline Zimbabwe & Hwange ecosystem $(25,000)$ & 120 & 72 & 168 & 4 (N. Monks) \\
\hline Zimbabwe & Mana Pools NP $(14,000)$ & 97 & 83 & 112 & 6 (N. Monks) \\
\hline Zimbabwe & Matetsi Safari Area $(1,343)$ & 60 & 36 & 84 & 4 (N. Monks) \\
\hline Zimbabwe & Matusadona NP $(16,000)$ & 120 & 72 & 168 & 4 (N. Monks) \\
\hline Zimbabwe & Sapi Safari Area $(1,526)$ & 40 & 24 & 56 & 4 (N. Monks) \\
\hline Zimbabwe & Zambezi NP (865) & 25 & 15 & 35 & 4 (N. Monks) \\
\hline Subtotal & Southern Africa & 10,000 & 7,500 & 12,500 & \\
\hline Total & & 23,000 & 16,500 & 30,000 & \\
\hline
\end{tabular}

${ }^{1}$ Area sizes, where available and as listed by East (1999), were not used for calculation of lion densities as most values do not include lion habitat adjacent to the area in question.

${ }^{2}$ Disputed or questioned, see text for details.

they may contain substantial numbers of lions. We believe that although surveys of lion populations for which no information is currently available will improve the precision of the estimate, it will not substantially increase the estimate of the current total. We conclude that this inventory represents the best possible conservative estimate of lion numbers at this time.

In West and Central Africa lion populations are generally small and isolated; they are declining in some protected areas and have virtually disappeared from non-protected areas, except southern Chad and northern Central African Republic (Bauer et al., 2003). A few populations exist in savannah patches in the Central African forests, but most lions in this region are found in the Sahel savannah belt. This belt is also extensively used by livestock and thus human-lion conflict is common. Lion density is typically $0.01-0.03 \mathrm{~km}^{-2}$ throughout the region, which is the low end of the density range in East and Southern Africa. This is due both to the naturally low biomass of mammals in the region (East, 1984), and to human influence (Oates, 1999; Fischer \& Linsenmair, 2001).

In East and Southern Africa many large lion populations have been stable over the last 3 decades. The Serengeti population, which has recovered from a canine distemper virus epidemic that caused 30\% mortality in 1994, is illustrative of their resilience (Roelke-Parker et al., 1996). Conservation is bolstered by revenue from safari hunting and tourism, allowing conservation in lands outside National Parks. An important challenge for long-term conservation in this region is political stability (Dudley et al., 2002). An example is the lion population in Akagera
National Park in Rwanda, currently estimated at 25, which before the recent civil war was estimated at 250 (Montfort, 1992).

This inventory supports the categorization of the lion as Vulnerable on the IUCN Red List, based on criterion C2a(i) (IUCN, 2001, 2002). For West and Central Africa our collation of data indicates that a categorization as Regionally Endangered (Gärdenfors et al., 2001) may be appropriate. Our estimate overlaps with the low end of the educated guess by Nowell \& Jackson (1996), but as their methodology of data collation was different from ours it is not possible to draw any conclusions concerning trends over time. This inventory is the first step towards a regularly updated African Lion Database for the monitoring of population trends. To this end, we recommend that areas with no or low quality information are surveyed in the near future and that other surveys are regularly updated.

\section{Acknowledgements}

The authors merely collated the available information, and credit for all surveys and censuses goes to the sources, as listed in Table 1. We are grateful to the many people who put us in contact with these many individuals and to all members of the IUCN African Lion Working Group, especially Johan Naude. In addition, we acknowledge the assistance of (alphabetically) J. Blanc, A. Blom, G.H. Boakye, W.T. De Groot, J. Hangcock, H.H. de Iongh, P. Jackson, D. Ngantou, M.G.L. Mills, J.O. Ogutu, C. Packer, F.P.G. Princée, J.P. Scott, U.S. Seal, R. Slotow, C. and T. Stuart, H.A. Udo de Haes and M. van 't Zelfde. 


\section{References}

Bauer, H., De Iongh, H.H., Princée, F.P.G. \& Ngantou, D. (eds) (2001) Status and Needs for Conservation of Lions in West and Central Africa. IUCN Conservation Breeding Specialist Group, Apple Valley, USA.

Bauer, H., De Iongh, H.H., Princée, F.P.G. \& Ngantou, D. (2003) Research needs for conservation of lions in West and Central Africa. Comptes Rendus Biologies, 326, S112-S118.

Creel, S. \& Creel, N.M. (1997) Lion density and population structure in the Selous Game Reserve: evaluation of hunting quotas and offtake. African Journal of Ecology, 55, 83-93.

Dudley, J.P., Ginsberg, J.R., Plumptre, A.J., Hart, J.A. \& Campos, L.C. (2002) Effects of war and civil strife on wildlife and wildlife habitats. Conservation Biology, 16, 319-329.

Dupuy, A.R. \& Verschuren, J. (1977) Wildlife and Parks in Senegal. Oryx $14,36-46$.

East, R. (1984) Rainfall, soil nutrient status and biomass of large African savanna mammals. African Journal of Ecology, 22, 245-270.

East, R. (1999) African Antelope Database 1998. IUCN, Gland, Switzerland.

Fischer, F. \& Linsenmair, K.E. (2001) Decrease in ungulate population densities. Examples from the Comoé National Park, Ivory Coast. Biological Conservation, 101, 131-135.

Gärdenfors, U., Hilton-Taylor, C., Mace, G.M. \& Rodriguez, J.M. (2001) The application of IUCN Red List criteria at regional levels. Conservation Biology, 15, 1206-1212.

Garnett, T. \& Utas, C (2000) The Upper Guinea Heritage, Nature Conservation in Liberia and Sierra Leone. Netherlands Committee for IUCN, Amsterdam, The Netherlands.

IUCN (2001) IUCN Red List Categories and Criteria: Version 3.1. IUCN, Gland, Switzerland.

IUCN (2002) 2002 IUCN Red List of Threatened Species. IUCN, Gland, Switzerland [http://www.redlist.org, accessed 16 September 2003].

Loveridge, A.J., Lynam, T. \& Macdonald, D.W. (compilers) (2001) Lion Conservation Research, Workshop1: Survey Techniques. Wildlife Conservation Research Unit, University of Oxford, Oxford, UK.

Mills, M.G.L., Juritz, J.M. \& Zuccini, W. (2001). Estimating the size of spotted hyena (Crocuta crocuta) populations through playback recordings allowing for non-response. Animal Conservation, 4, 335-343.

Montfort, A. (1992) Première liste commentée des mammifères du Rwanda. Journal of African Zoology, 106, 141-151.

Nowell, K. \& Jackson, P. (eds) (1996) Wild Cats, Status Survey and Conservation Action Plan. IUCN, Gland, Switzerland.
Oates, J.F. (1999) Myth and Reality in the Rainforest: How Conservation Strategies are Failing in West Africa. University of California Press, Berkeley, USA.

Ogutu, J.O. \& Dublin, H.T. (1998) The response of lions and spotted hyenas to sound playbacks as a technique for estimating population size. African Journal of Ecology, 36, 83-95.

Ogutu, J.O. \& Dublin, H.T. (2002) Demography of lions in relation to prey and habitat in the Maasai Mara National Reserve, Kenya. African Journal of Ecology, 40, 120-129.

Pennycuick, C.J. \& Rudnai, J. (1970) A method of identifying individual lions Panthera leo with an analysis of the reliability of identification. Journal of Zoology London, 160, 497-508.

Roelke-Parker, M.E., Munson, L., Packer, C., Kock, R., Cleaveland, S., Carpenter, M., O'Brien, S.J., Pospischil, A., Hofman-Lehmann, R., Lutz, H., Mwamengele, G.L.M., Mgasa, M.N., Machange, G.A., Summers, B.A. \& Appel, M.J.G. (1996) A canine distemper virus epidemic in Serengeti lions (Panthera leo). Nature, 379, 441-445.

Smuts, G.L., Whyte, I.J. \& Dearlove, T.W. (1977) A mass capture technique for lions. East African Wildlife Journal, 15, 81-87.

Stander, P.E. (1998) Spoor counts as indices of large carnivore populations: the relationship between spoor frequency, sampling effort and true density. Journal of Applied Ecology, 35, 378-385.

Van Orsdol, K.G., Hanby, J.P. \& Bygott, J.D. (1985) Ecological correlates of lion social organization (Panthera leo). Journal of Zoology London, 206, 97-112.

\section{Biographical sketches}

Hans Bauer has been studying human-wildlife conflict in northern Cameroon since 1993. From 1996 to 2000 he was coordinator of the Centre for Environment and Development studies in Cameroon, dealing with participatory research techniques, co-management of natural resources and the integration of social and natural science.

Sarel Van Der Merwe has worked on soil conservation and with the South African National Parks Board, and since 1980 he has been Curator of the Bloemfontein Zoo and Head of the Division of Natural Resource Management of the Mangaung Local Municipality in South Africa. He is comanager of the African Large Predator Research Unit of the University of the Free State, and chair and founder-member of the African Lion Working Group. 